\title{
POST-TRAUMATIC EROSIONS OF ARTICULAR CARTILAGE
}

\author{
H. V. Crock, Melbourne, Australia \\ From St Vincent's Hospital, Melbourne
}

Erosions of articular cartilage are often seen in the knee joint in association with certain internal derangements such as meniscus tears or after recurrent subluxation of the patella (Helfet 1959, Smillie 1962). Also a number of studies have appeared on the pathology of articular cartilage after injury, both in man (Landells 1957) and in experimental animals (Barnett 1956. Tallqvist 1962, Meachim 1963). However, attention does not appear to have been directed towards the clinical diagnosis and management of isolated articular cartilage erosions after injury, with the exception of several papers bearing on the patella (Büdinger 1908; Wiles, Andrews and Devas 1956).

The present paper deals with sixteen patients with articular cartilage injuries in various joints (Table I). These lesions predispose to osteoarthritis in the affected joints, although the

TABLE I

Joints Affected by Articular Cartilage Erosions

\begin{tabular}{|c|c|c|c|}
\hline \multicolumn{2}{|c|}{ Joint involved } & & Number of patients \\
\hline Hip & . & . & 1 \\
\hline Knee & . & . & 11 \\
\hline Elbow & . & . & 1 \\
\hline Wrist & . & & 3 \\
\hline
\end{tabular}

evolution of this process may be measured in years. Meanwhile, a number of disabling symptoms and signs, varying with the pathology in individual cases, can be attributed to the cartilage erosions (Figs. 1, 2, 5 and 6).

In this series diagnosis was confirmed at operation in every patient. Although the treatment is described the real purpose of the paper is to draw more attention to a condition which is neglected clinically.

Clinical features-A specific history of injury was obtained from each patient. Shearing stresses or direct compression forces of short duration seemed to be the cause of the lesions. For example, one patient injured the articular cartilage of the carpal scaphoid bone by wrenching her wrist when she grasped a bannister to save herself while falling downstairs. Another developed symptoms in his right knee after jarring his leg while digging in heavy clay. A third developed pain and recurrent swelling in the left knee after striking the lateral aspect of the femoral condyle against the sharp edge of a desk.

The value of knowing the direction and nature of the force producing fractures has been described by Perkins (1956). In the present context this knowledge is also of great importance provided that the clinician appreciates that the force may have damaged the articular cartilage. This aspect of an injury to a joint is rarely considered in the surgical teaching of students, especially when the injury has not caused bony damage.

The main symptoms were found to be pain, joint swelling, and transient and intermittent crepitus with stiffness or instability of weight-bearing joints (Table II). Usually the pain was not severe, but had a dull, persistent aching character. In the lower limb standing aggravated the pain, as did movement or lifting in the upper limb. 


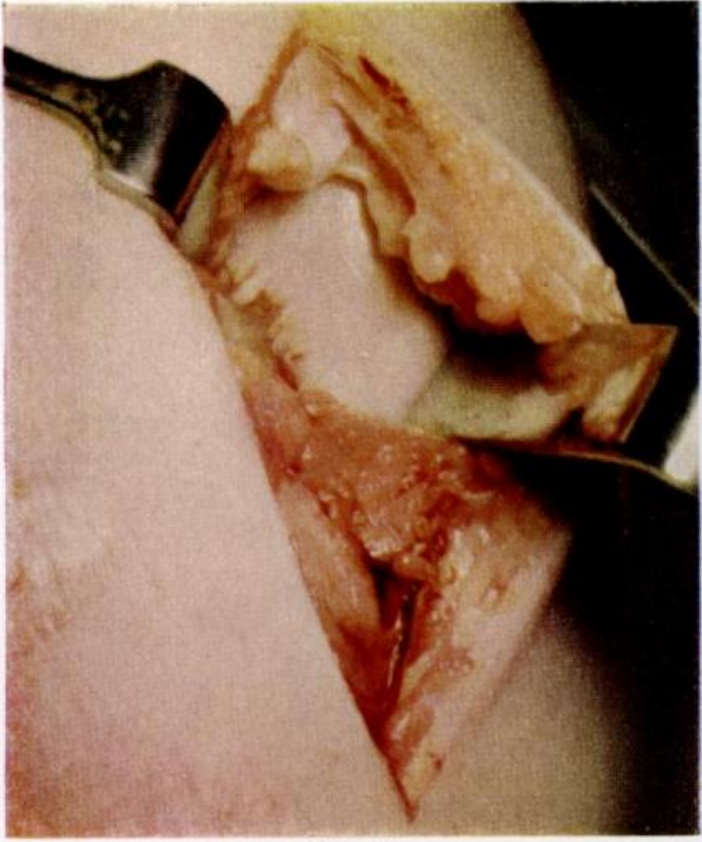

FIG. 1

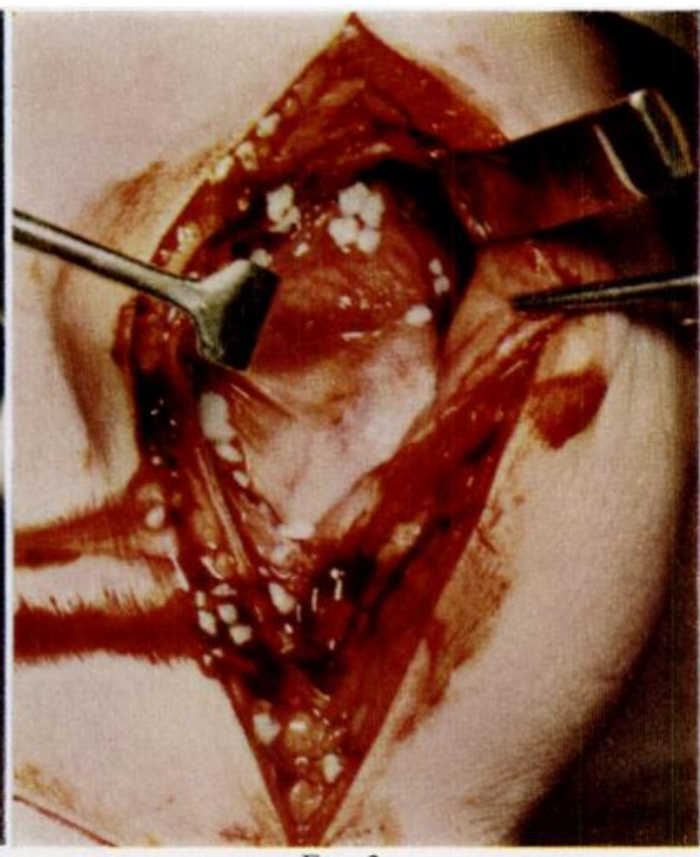

FIG, 2

Case 2. Figure 1-The medial femoral condyle of the right knee joint at operation showing the articular cartilage erosion near the outer border of the condyle. The cruciate ligaments and medial meniscus were normal Figure 2-The multiple nodular cartilaginous loose bodies which had come from the articular cartilage lesion on the medial femoral condyle, shown through a lateral incision. Synovial crepitus had been a constant sign on clinical examination of this joint over many months.

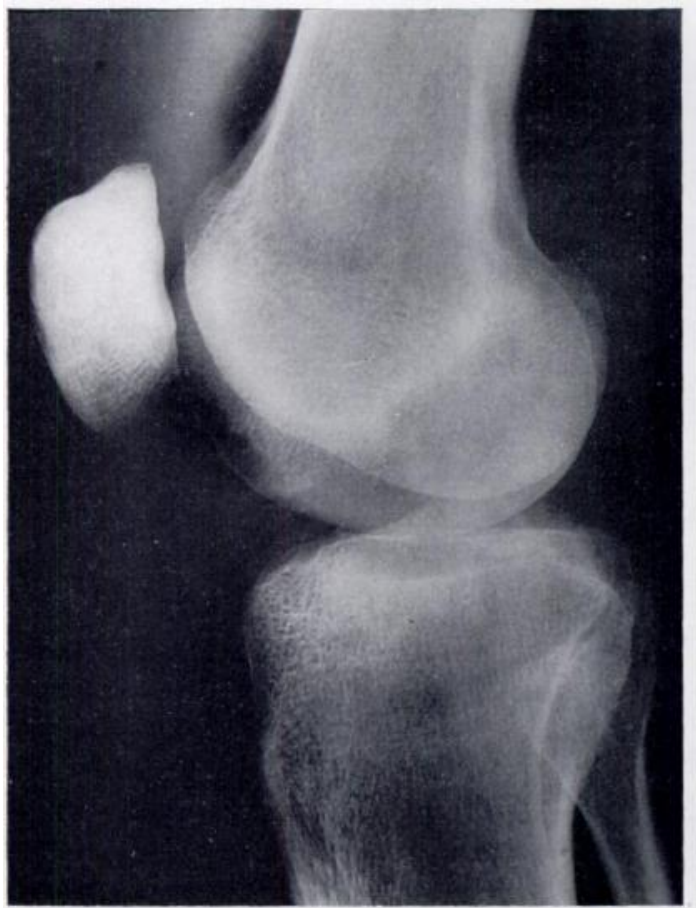

FIG. 3

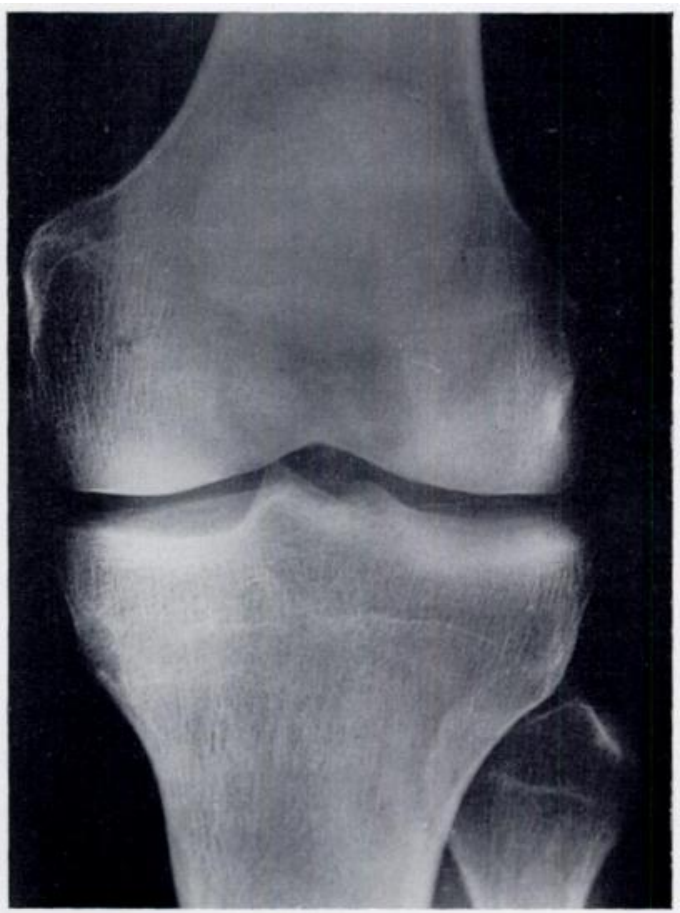

FIG. 4

Figure 3-Case 2. A lateral radiograph of the right knee joint showed the localised subarticular osteoporosis at the femoral condyle. Figure 4-Case 3. An antero-posterior radiograph of the right knee joint. There was an extensive area of damage to the articular cartilage of the lateral tibial plateau, and the localised subarticular osteoporosis was confined to this part.

VOL. $46 \mathrm{~B}$, NO. 3, AUGUST 1964

$\mathrm{L}_{(8)}$ 
H. V. CROCK

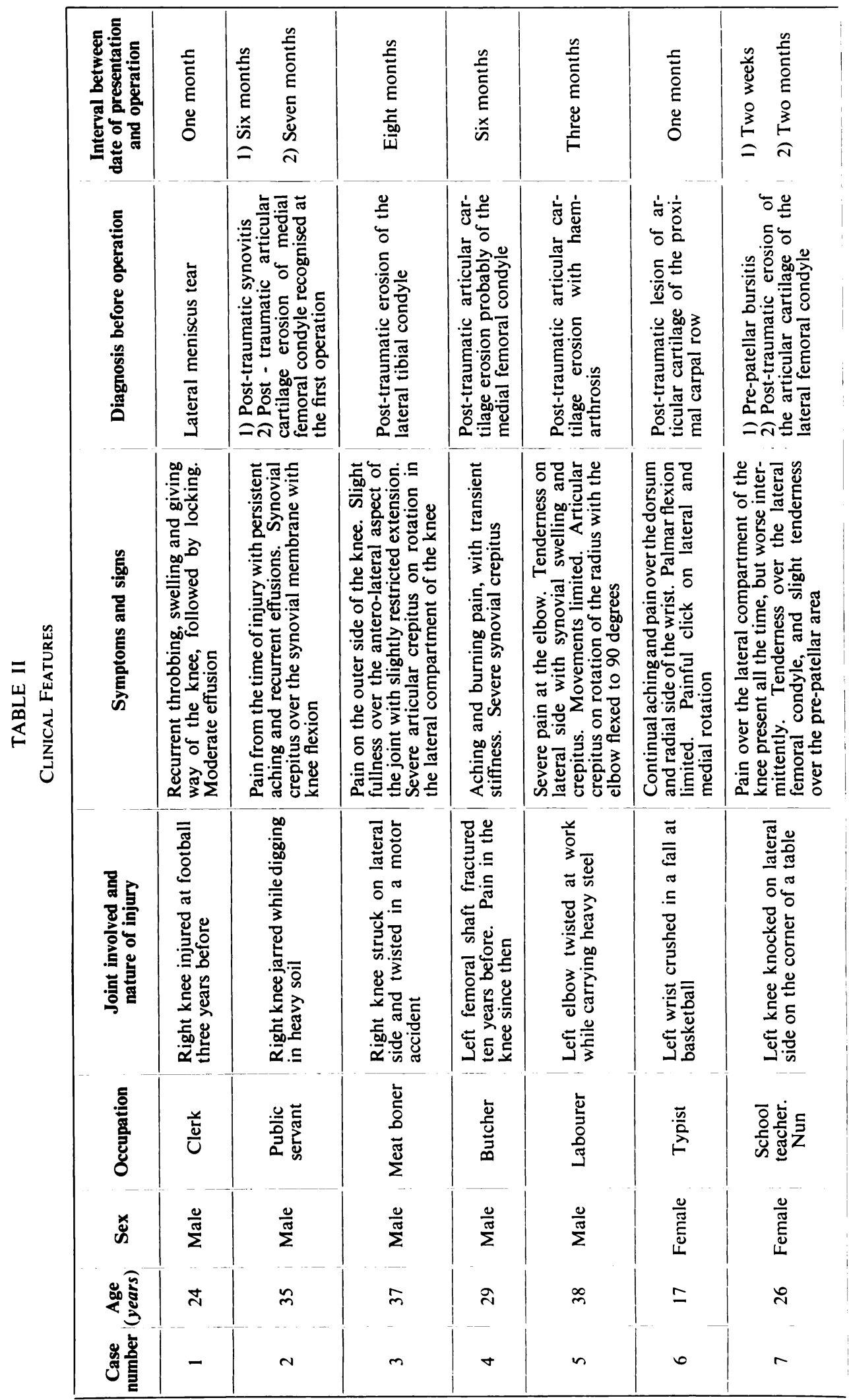

THE JOURNAI. OF BONE AND JOINT SURGERY 
POST TRAUMATIC EROSIONS OF ARTICULAR CARTILAGE

\begin{tabular}{|c|c|c|c|c|c|c|c|c|}
\hline 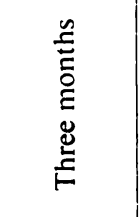 & 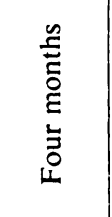 & 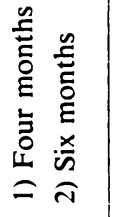 & 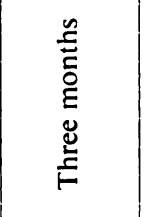 & 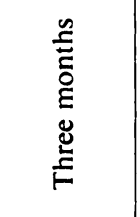 & 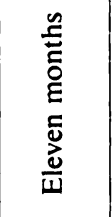 & 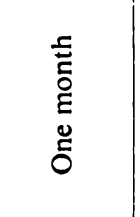 & 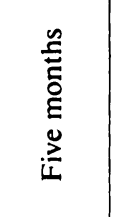 & 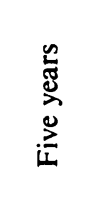 \\
\hline 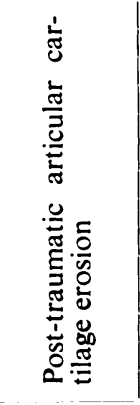 & 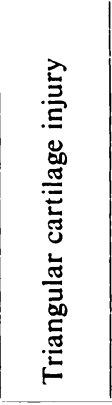 & 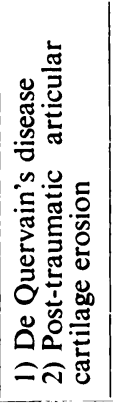 & 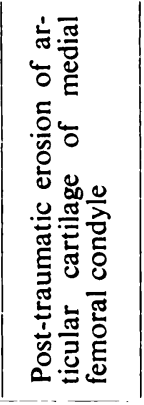 & 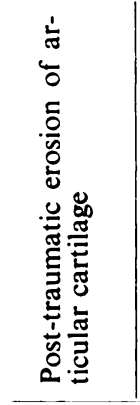 & 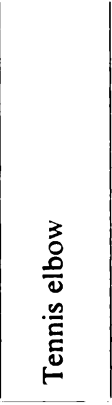 & 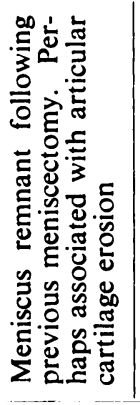 & 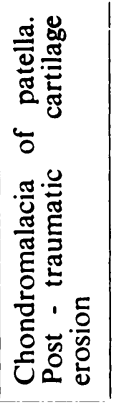 & 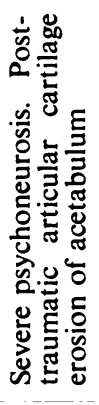 \\
\hline 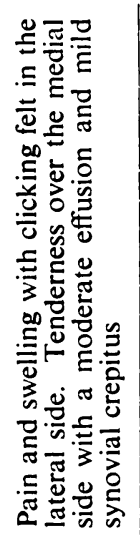 & 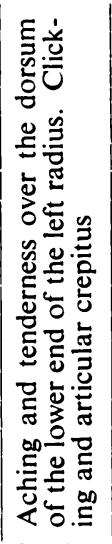 & 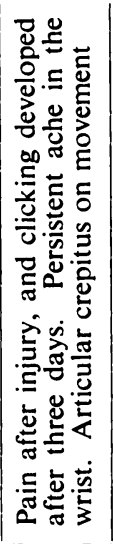 & 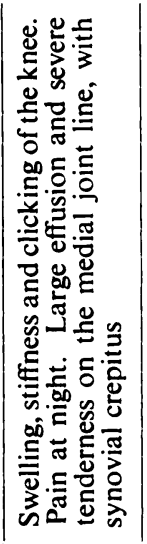 & 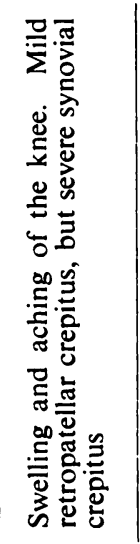 & 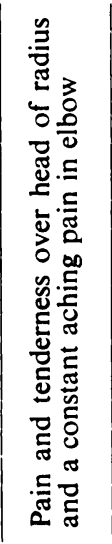 & 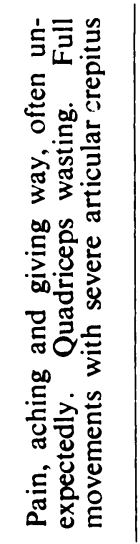 & 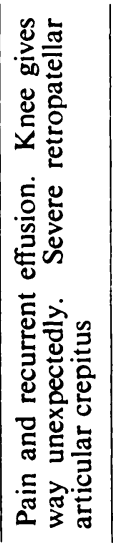 & 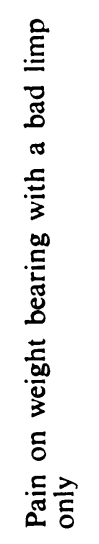 \\
\hline 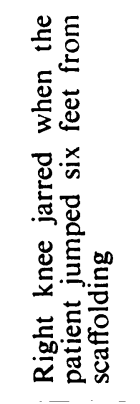 & 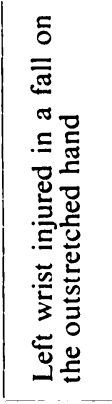 & 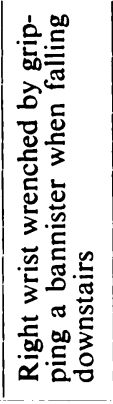 & 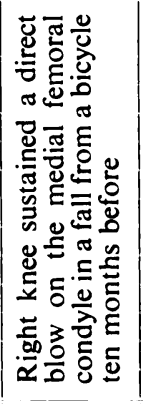 & 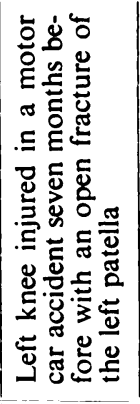 & 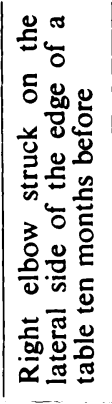 & 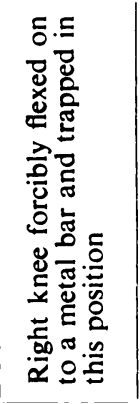 & 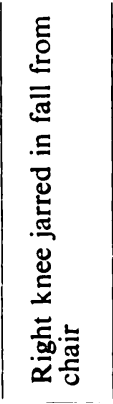 & 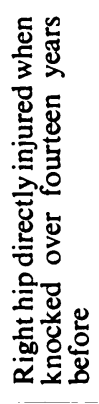 \\
\hline 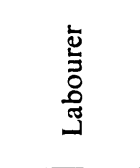 & 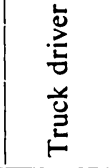 & $\begin{array}{l}\frac{\vec{n}}{2} \\
\vec{n}\end{array}$ & 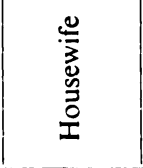 & 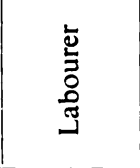 & 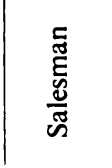 & 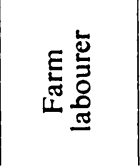 & 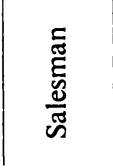 & 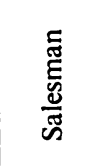 \\
\hline$\frac{\frac{0}{\sigma}}{\Sigma}$ & $\frac{0}{\frac{0}{\pi}}$ & $\begin{array}{l}\frac{0}{\tilde{J}} \\
\tilde{\Sigma} \\
\end{array}$ & 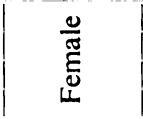 & $\frac{0}{\tilde{\pi}^{\pi}}$ & $\frac{0}{\tilde{\sigma}}$ & $\frac{\omega}{\tilde{N}}$ & $\frac{\frac{0}{\pi}}{\Sigma}$ & $\frac{0}{\frac{0}{\pi}}$ \\
\hline$\approx$ & ర్లి & 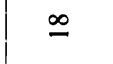 & "̈ & $\bar{\sim}$ & $\vartheta$ & $\bar{m}$ & $\mathscr{f}$ & 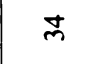 \\
\hline$\infty$ & $a$ & 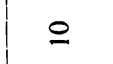 & $=$ & $\simeq$ & $\cong$ & \pm & $\simeq$ & $\cong$ \\
\hline
\end{tabular}


The physical signs varied with the nature, extent and localisation of the articular cartilage erosions. Moderate effusions were seen more commonly in affected knees than in any other joints. The effusion tended to recur or even to persist during the many months of observation before surgery, but after operation it always subsided and did not recur. Crepitus was a valuable sign, occurring in two quite distinct forms. The first, which will be called " articular crepitus." resembled the familiar joint crepitus of osteoarthritis or of chondromalacia. It could be elicited only when the damaged area of cartilage was examined. For example. it may have been found in an affected knee joint while the tibia was being rotated on the femoral condyles with the joint flexed to 95 degrees-but in no other position. The second, which will be called "synovial crepitus," resembled that which can be felt over a tendon sheath in acute tenosynovitis. This was a unique physical sign which was often transient. It was due

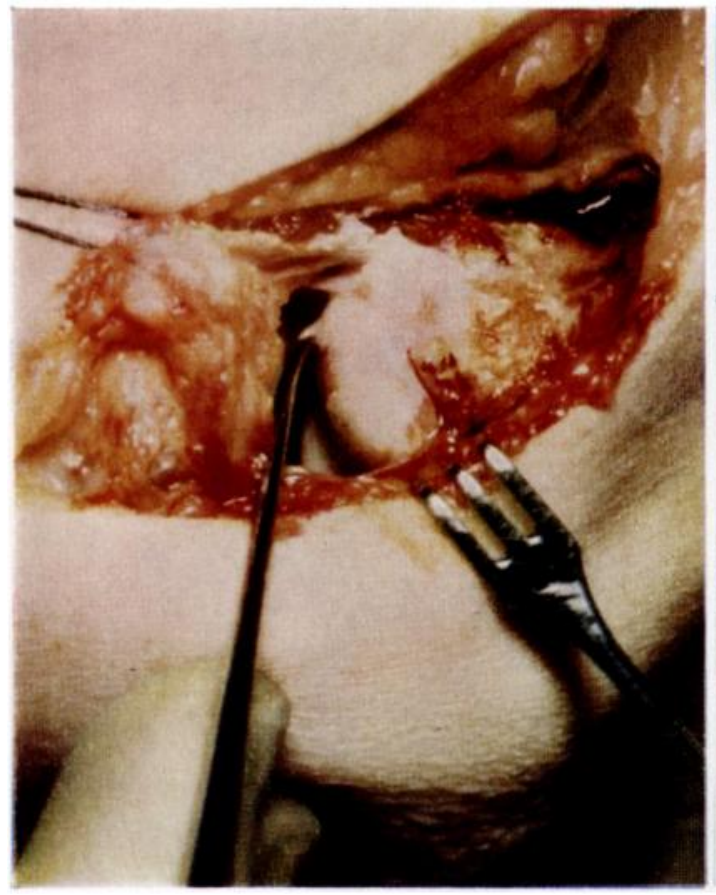

FIG. 5

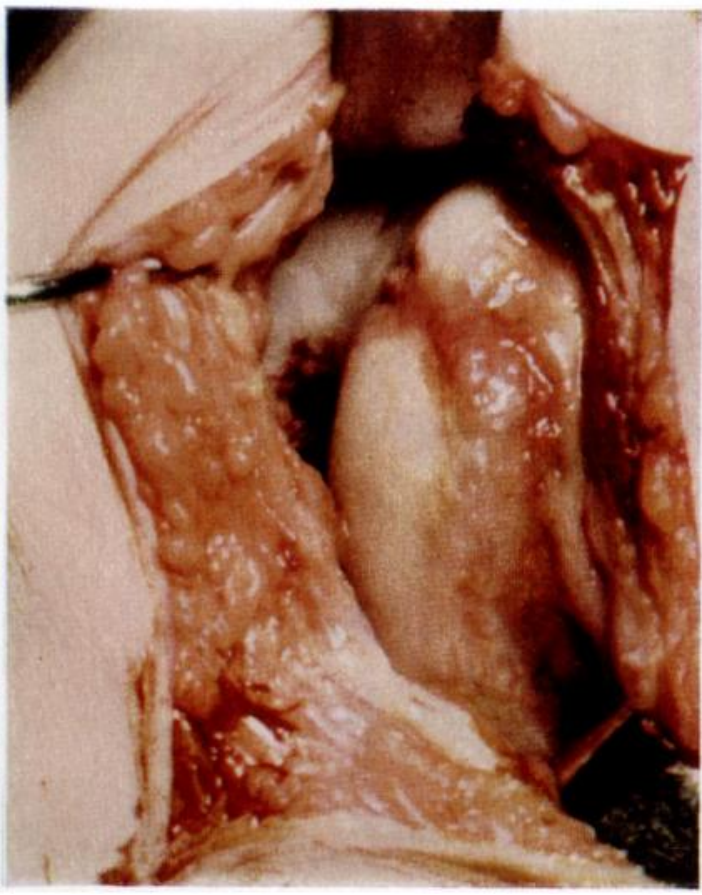

Fig. 6

Figure 5-Case 5. The left elbow, opened from the lateral aspect, to show the articular cartilage erosion on the capitulum. Articular crepitus was produced before operation by rotating the head of the radius on the humerus with the elbow flexed to 90 degrees. Figure 6-Case 12. The right knee joint, opened from the medial side. showing the marginal articular cartilage lesion. Note the ridging of the articular surface of the medial femoral condyle and the ingrowth of pannus. Synovial crepitus had been a prominent physical sign.

either to the movement of fine cartilaginous loose bodies caught between gliding synovial membranes or to the uneven movements of synovial membrane across a ridged area of cartilage covered with pannus (Fig. 6). Some restriction of joint movement was common. especially at the elbow and wrist. However, under anaesthesia the range of movement was normal.

Radiography revealed areas of localised subarticular osteoporosis in a few patients (Figs. 3 and 4). This sign was regarded as a useful aid in diagnosis. The anatomy of the subchondral circulation in adult bones is complex, particularly on the venous side (Crock 1962). It is suggested here that the resorption of metabolites from the damaged area of cartilage may provoke a twofold response: firstly, that this is probably one factor in the production of the reactionary effusion, and secondly, that resorption of these products through the subchondral 
capillary bed may provoke a response in the subarticular venous plexus, which leads to this peculiar localisation of the osteoporosis.

It is not possible to offer any suggestion on the frequency of this radiographic finding in patients with articular cartilage erosion after injury. However, these observations are presented in the belief that they may be of significance in helping to establish this diagnosis. Findings at operation-Joint fluid was usually excessive and contained slimy remnants of minute articular cartilage flakes or multiple small nodular loose bodies (Fig. 2). The synovial membrane and other intra-articular structures such as ligaments or menisci, appeared normal. When the articular cartilage lesions were situated at some distance from the joint margins their appearances varied from nodular swellings to fissured cracks or erosions surrounded by discrete flakes of cartilage with rounded free edges (Figs. 1 and 5).

Wiles et al. (1956) described the naked-eye appearances of chondromalacia of the patella as follows: "The nodular area is lustreless and grey or yellow in colour, and it is distinct from the glistening, blue normal cartilage surrounding it." This is an excellent description which applies admirably to some of the lesions in this series. A feature of marginal articular cartilage injuries was the ingrowth of a highly vascular, flat, thin pannus from the adjacent synovial membrane, which sometimes produced localised ridging of the synovial tissues. In these cases the physical sign of "synovial crepitus" had been found before exploration (Fig. 6).

At operation the lesions were dealt with either by shaving of the affected areas of cartilage until smooth surfaces presented or by combining the shaving procedure with closely approximated drill holes penetrating the subchondral bone plates. The diameters of the drills used varied between one millimetre for carpal bones and four millimetres for the femoral condyles.

When articular cartilage erosion occurred in weight-bearing areas, and in which drilling of the subchondral bone plate had been done, weight bearing was not allowed for three months after operation. However, early movement was encouraged irrespective of the method of surgical treatment of the cartilage lesion.

The results of treatment are set out in Table III.

\section{DISCUSSION}

Isolated lesions of articular cartilage may be found after injury which has otherwise produced neither damage to the bone nor to the other components of a joint.

For many years the role of injuries in the production of chondromalacia of the patella has been recognised. However, even in this condition, some unknown primary cause of articular cartilage degeneration has usually been implicated-the injury simply aggravating the condition-to produce the characteristic local changes such as fissuring or flaking (Wiles et al. 1956). Some of the patients in this series fit into the category of the description by Wiles and his colleagues. However, in others the only demonstrable lesions in the affected joints were localised cartilage erosions, and the adjacent articular cartilage was normal.

There is, therefore, a clear distinction to be drawn between, on the one hand, joints in which a wide area of articular cartilage is softened and frankly abnormal to examination at the time of operation - and in which there also exists some local change of fissuring or flaking and, on the other hand, those in which all the joint cartilage appears and feels normal, with the exception of a local erosion. In the first instance an injury has aggravated a primary degenerative condition, whereas in the second it has produced a local erosion in otherwise normal cartilage.

The diagnosis of primary post-traumatic articular cartilage erosion is difficult to establish. If the existence of the lesion were to be more generally appreciated, then the diagnosis would be established more often. It is important that this should be so, because it can cause protracted

VOL. 46 B, NO. 3, AUGUST 1964

$\mathrm{L}-1_{(8)}$ 
TABLE III

Findings, Treatment and Results

\begin{tabular}{|c|c|c|c|c|}
\hline $\begin{array}{c}\text { Case } \\
\text { number }\end{array}$ & $\begin{array}{l}\text { Radiographic } \\
\text { findings }\end{array}$ & Findings at operation & Treatment & Result \\
\hline 1 & Normal & $\begin{array}{l}\text { Moderate effusion with flakes } \\
\text { of cartilage floating in the joint } \\
\text { from an erosion on the upper } \\
\text { anterior segment of the tibial } \\
\text { articular cartilage. Menisci } \\
\text { normal }\end{array}$ & $\begin{array}{l}\text { Removal of loose bodies. } \\
\text { Shaving of the articular car- } \\
\text { tilage on the lateral tibial } \\
\text { condyle }\end{array}$ & $\begin{array}{l}\text { No effusion. Full } \\
\text { movements. Symp- } \\
\text { tomless. Last seen } \\
\text { four months later }\end{array}$ \\
\hline 2 & $\begin{array}{l}\text { Localised sub- } \\
\text { articular osteo- } \\
\text { porosis over } \\
\text { lower end of the } \\
\text { femoral condyle } \\
\text { (Fig. 3) }\end{array}$ & $\begin{array}{l}\text { Multiple loose bodies. Local- } \\
\text { ised area of articular cartilage } \\
\text { erosion on the medial femoral } \\
\text { condyle (Figs. } 1 \text { and } 2 \text { ) }\end{array}$ & $\begin{array}{l}\text { Lateral arthrotomy of the } \\
\text { knee. Diagnosis established. } \\
\text { Removal of loose bodies. } \\
\text { Shaving of articular cartilage } \\
\text { and drilling of subchondral } \\
\text { bone plate }\end{array}$ & $\begin{array}{l}\text { No effusion. No } \\
\text { crepitus. Full ex- } \\
\text { tension. Slight } \\
\text { loss of full flexion. } \\
\text { Last seen sixteen } \\
\text { months later }\end{array}$ \\
\hline 3 & $\begin{array}{l}\text { Localised sub- } \\
\text { articular osteo- } \\
\text { porosis over the } \\
\text { right lateral } \\
\text { tibial plateau } \\
\text { (Fig. 4). }\end{array}$ & $\begin{array}{l}\text { Extensive articular cartilage } \\
\text { erosion over the tibial plateau, } \\
\text { and on the posterior half of the } \\
\text { lateral femoral condyle }\end{array}$ & $\begin{array}{l}\text { Affected condyles of tibia } \\
\text { and femur shaved, and one- } \\
\text { millimetre drill holes made }\end{array}$ & $\begin{array}{l}\text { No effusion. No } \\
\text { synovial crepitus. } \\
\text { No tibio-femoral } \\
\text { crepitus in lateral } \\
\text { c o m p r t m e n t. } \\
\text { Movements normal. } \\
\text { Last seen seven } \\
\text { months later }\end{array}$ \\
\hline 4 & Normal & $\begin{array}{l}\text { Large erosion of the medial } \\
\text { femoral condyle. } \\
\text { synovial tissues }\end{array}$ & $\begin{array}{l}\text { Shaving of the medial con- } \\
\text { dyles of the tibia and femur }\end{array}$ & $\begin{array}{l}\text { No residual symp- } \\
\text { toms. Full move- } \\
\text { ment of knee. Last } \\
\text { seen fourt een } \\
\text { months later }\end{array}$ \\
\hline 5 & $\begin{array}{l}\text { Subarticular } \\
\text { osteoporosis in } \\
\text { lateral view of } \\
\text { left capitulum }\end{array}$ & $\begin{array}{l}\text { Localised articular cartilage } \\
\text { erosion of capitulum (Fig. 5) }\end{array}$ & Shaving of eroded area & $\begin{array}{l}\text { Symptoms partly } \\
\text { relieved. Last seen } \\
\text { nine months later }\end{array}$ \\
\hline 6 & Normal & $\begin{array}{l}\text { Cracked cartilage on radial } \\
\text { surface of the lunate bone }\end{array}$ & $\begin{array}{l}\text { Shaving of proximal articular } \\
\text { cartilage of lunate }\end{array}$ & $\begin{array}{l}\text { Symptomless. Full } \\
\text { movements. Last } \\
\text { seen four months } \\
\text { later }\end{array}$ \\
\hline 7 & Normal & $\begin{array}{l}\text { Pre-patellar bursitis. } \\
\text { Localised articular cartilage } \\
\text { erosion on the lateral edge of } \\
\text { the lateral femoral condyle. } \\
\text { Severe injection of the synovial } \\
\text { membrane locally, but no } \\
\text { pannus formation }\end{array}$ & $\begin{array}{l}\text { Excision of the pre-patellar } \\
\text { bursa } \\
\text { Shaving of affected zone of } \\
\text { cartilage }\end{array}$ & $\begin{array}{l}\text { Symptoms un- } \\
\text { changed after the } \\
\text { first operation } \\
\text { Improved after the } \\
\text { second operation. } \\
\text { Last seen four } \\
\text { months later }\end{array}$ \\
\hline 8 & Normal & $\begin{array}{l}\text { Effusion into the joint with } \\
\text { whitish flakes of soft gelatin- } \\
\text { ous material. Two parallel } \\
\text { longitudinal splits in the artic- } \\
\text { ular cartilage in the inter- } \\
\text { condylar area of the femur, } \\
\text { with soft flaky articular car- } \\
\text { tilage between them. A similar } \\
\text { lesion of the medial articular } \\
\text { facet of the patella }\end{array}$ & $\begin{array}{l}\text { Cartilage of the patella and } \\
\text { femur shaved and the femoral } \\
\text { condyle drilled }\end{array}$ & $\begin{array}{l}\text { Improved. Last } \\
\text { seen two months } \\
\text { later }\end{array}$ \\
\hline
\end{tabular}


TABLE III-continued

Findings, Treatment AND Results

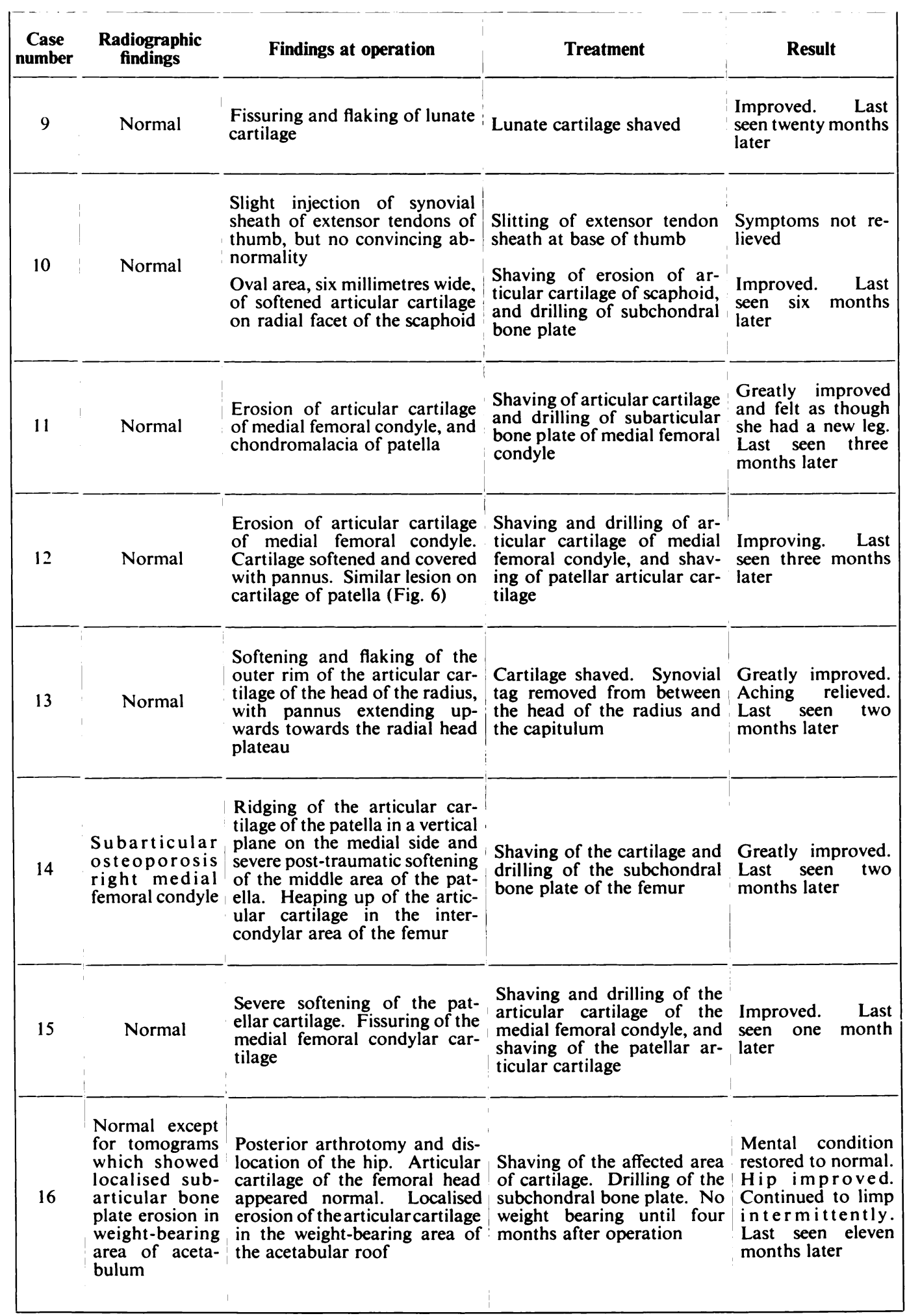

vol. 46 B, No. 3, AUGUST 1964 
disability after joint injury. Some of the patients in the present series had been disabled for years before the underlying cause was recognised and treated. In the meantime they had been labelled as psychoneurotics. The clinical picture of recurrent effusions, persisting aching pain in the joint together with the signs of crepitus of two distinct varieties, after a specific injury should bring this diagnosis to mind.

Radiography may provide useful confirmatory evidence if the sign of localised subarticular osteoporosis can be demonstrated. Tomography is also sometimes useful. The anatomical basis of the radiographic findings in this condition has been discussed.

In regard to treatment, no authoritative statement can be made at the present time. From the results presented in this series it is clear that shaving of the affected area of articular cartilage may be useful in preventing the shedding of loose bodies into the joint. There is no general agreement on the potentialities of articular cartilage for repair after shaving.

The rationale of drilling the subchondral bone plate has been discussed in the management of osteoarthritis of the knee, but its application to the treatment of articular cartilage erosion appears reasonable (Pridie 1959).

\section{SUMMARY}

1. Sixteen patients with articular cartilage erosions after slight injury have been described, as have the results of their treatment.

2. The clinical features of this rarely diagnosed condition are discussed. Attention is drawn to "articular crepitus" and "synovial crepitus" as useful physical signs in establishing the diagnosis.

3. A radiographic sign of localised subarticular osteoporosis is reported and discussed.

4. The surgical treatment used was either shaving of the affected area of cartilage or a combination of shaving with drilling of the subchondral bone plate.

I wish to thank my wife, Dr M. C. Crock, and Miss M. Philipps for their help in preparing this paper. The photographs were produced with great care by Mr A. Daniel and Mr E. Moir, whose assistance I appreciate. I thank also Dr Gordon Donnan and Dr P. H. Cody who offered useful comments on the radiographic findings.

\section{REFERENCES}

BARNeTt, C. H. (1956): Wear and Tear in Joints. Journal of Bone and Joint Surgery, 38-B, 567.

BüDINGER, K. (1908): Über traumatische Knorpelrisse im Kniegelenk. Deutsche Zeitschrift für Chirurgie, $92,510$.

Crock, H. V. (1962): The Arterial Supply and Venous Drainage of the Bones of the Human Knee Joint. Anatomical Record, 144, 199.

Helfet, A. J. (1959): Mechanism of Derangements of the Medial Semilunar Cartilage and their Management. Journal of Bone and Joint Surgery, 41-B, 319.

Landells, J. W. (1957): The Reactions of Injured Human Articular Cartilage. Journal of Bone and Joint Surgery, 39-B, 548.

Meachim, G. (1963): The Effect of Scarification of Articular Cartilage in the Rabbit. Journal of Bone and Joint Surgery, 45-B, 150.

Perkins, G. (1956): The Value of Knowing the Direction and Nature of the Force Causing a Fracture. Journal of Bone and Joint Surgery, 38-B, 227.

Pridie, K. H. (1959): A Method of Resurfacing Osteoarthritic Knee Joints. Journal of Bone and Joint Surgery, 41-B, 618.

SmiLlie, I. S. (1962): Injuries of the Knee Joint. Third edition. London and Edinburgh: E. \& S. Livingstone Ltd.

TAllovist, G. (1962): The Reaction to Mechanical Trauma in Growing Articular Cartilage. Acta Orthopaedica Scandinavica, Supplementum 53.

Wiles, P., Andrews, P. S., and Devas, M. B. (1956): Chondromalacia of the Patella. Journal of Bone and Joint Surgery, 38-B, 95. 